\title{
SHAKESPEARE'S RECEPTION IN ITALY: TWO TRANSLATIONS OF THE TEMPEST. A CASE STUdY
}

\author{
Giuseppe Barbuscia, University of Mostar, Bosnia and Herzegovina, \\ g.barbuscia@gmail.com
}

$10.31902 /$ fll.24.2018.4 UDK 821.111.09Šekspir V. UDK821.111-2: 82.035(450)

\begin{abstract}
Literary fortune, as eternal and immutable as it might seem in some cases, is always the result of a complex process of mediation, made of refusals, negotiations, misunderstandings, even feelings of repulsion and devotion. In other words, literary fame is rather a destination than a destiny. If Shakespeare acceptance in Europe was an exceptionally tortuous journey, him crossing the Alps proved even more problematic. All through the eighteenthcentury Shakespeare's presence in Italy was virtually non-existent, while the first translation of his complete works only appeared in 1831. The first performance of a Shakespeare play to ever be attempted in Italy was staged around 1843, proving a remarkable fiasco. Two more decades will have to pass before a play meets the audience's applause, namely Ernesto Rossi's staging of Othello in 1856. From that point, also thanks to the influence of melodrama, Shakespeare's slow process of canonization was on its way to completion.

The Italian case proves useful to understand how the processes literary canonization work. This paper analyzes what reasons may have led the Italian literary system to be so exceptionally resistant to Shakespeare, exploring how matters of ethnocentrism and chronocentrism are often at work when analyzing canonization.

Finally, the contrastive analysis of two translations of The Tempest (Leoni's from 1815 and Carcano's from 1860) will show how translation choices are dictated by the translator's ideology, thus often mirroring the cultural paradigms of the period in which they are produced, but also how fundamental they are in shaping those paradigms and ignite cultural change.
\end{abstract}

Keywords: Shakespeare, translation, manipulation, Italy, canonization, The Tempest, Leoni, Carcano, chronocentrism, ethnocentrism.

\section{Shakespeare's reception in Italy \\ Shakespeare's translations in eighteenth and nineteenth century Italy}

If Shakespeare's process of canonization in Europe was notoriously problematic, the diffusion of his work in Italy started even later and encountered considerable difficulties (Baretti; Bloom xv; 
Collison-Morley; Graf; Morandi; Zvereva). In the eighteenth century, Shakespeare was only just beginning to be taken into account in Europe, also thanks to Voltaire's influence (who later became a harsh opponent of the English playwright), while in Italy he was almost completely neglected. In the first half of the century there is only one mention of Shakespeare, in the preface of Antonio Conti's own play II Giulio Cesare: "Sasper [sic] is the Corneille of the English, only far more irregular than Corneille, though, like him, he is full of great ideas and noble sentiments" (Collison-Morley 6).

Shakespeare was completely unknown to Italians, except to those gentlemen who travelled to Britain and became acquainted with the English stage. Collison-Morley suggests that

the best proof of the absolute ignorance of Shakespeare that prevailed on the other side of the Alps during the early years of the eighteenth century is the fact that a man of Apostolo Zeno's vast learning could write a music-drama, Ambleto without ever having heard of Hamlet. (Collison Morley 4)

The first translation of a Shakespeare play appeared only in 1756 by Domenico Valentini, published in Siena with the title: I/ Giulio Cesare, Tragedia Istorica di Guglielmo Shakespeare. Some more attention was being paid to Shakespeare starting from the second half of the century. A translation of Hamlet was completed in 1768 by Alessandro Verri, who also translated Othello in 1777. An event of major significance was the publishing of the French translation of the complete Shakespeare in twenty volumes, between 1776 and 1783. Considering that every educated Italian could at least read French, while very few knew any English, Pierre Letourneur's Théâtre de Shakespeare represented the only way to access Shakespeare's complete works for most cultivated Italians. Around that time, the debate on Shakespeare's value as a playwright was growing ever more lively and bitter. By the turn of the century Shakespeare was a hot topic in Italy, as well as in the rest of Europe, with a few enthusiastic admirers and a disdainful majority. In 1798 a Venetian noblewoman, Giustina Renier Michiel, published a selection of plays that she had translated, including Coriolanus, Macbeth, and Othello. She had undertaken a systematic translation of Shakespeare since she was very young, but only those three plays were chosen for publication and we 
do not know the extent of the entire corpus. ${ }^{1}$ These works were not particularly remarkable, they were in prose and they were actually done from Letourner's version rather than from English, but they had some circulation at the time and they represent the first attempt of an extensive translation of Shakespeare. This task was to be better accomplished in 1814 by Michele Leoni, who managed to publish seven tragedies, mostly in verse: Julius Caesar, Hamlet, Romeo and Juliet, Cimbeline, Macbeth, Richard III and The Tempest, to which Othello was added in 1825. Leoni's translations did a lot to popularize Shakespeare in a moment when the debate on the English writer was at its height. The first decades of the nineteenth century were fundamental for Shakespeare's fame in Italy, as the influence of the Romantic movement was bringing about more favourable opinions, while the new generations were more open to accept some of Shakespeare's features that were inadmissible but a few years before. Still, the process was all but smooth. Leoni's was the widest corpus of Shakespeare translations that was ever published until the publication of the first complete Shakespeare in Italian by Carlo Rusconi in 1831. The early 1830s were a prolific moment for translations: Valletta, Soncini, Barbieri and Nicolini translated, in the same period, several the single most popular plays, while Giunio Bazzoni and Giacomo Sornani published together a collection of six translations. This adds up to a total of thirteen single translations, plus Rusconi's complete corpus, only between 1829 and 1830, a clear sign of how seriously Shakespeare's position in the Italian literary system was changing. No other translations were afterwards made though, with the exception of Carcano's, who published a selection in 1843, then expanded it in 1857 and finally published the complete works from 1875 to 1882, the second complete edition in Italy, as well as the last one in the nineteenth century.

\section{Theatre productions, melodrama, ballet}

Even if after the 1830s there are no other significant translations to signal, at this point the corpus of translated works is quite consistent, with the most popular tragedies counting several versions. This does not imply that Shakespeare's question was settled.

\footnotetext{
${ }^{1}$ An anecdote on this woman and her translations has Napoleon as a protagonist. During a visit of the emperor to Venice in 1807, she was signalled to him as a translator of tragedies. He asked "Racine, I suppose?" but, at hearing the answer, he turned his back upon her in spite (Collison-Morley 78).
} 
The first theatre production of a Shakespeare play, by Gustavo Modena, came as late as 1843 (the date is approximate) and it was the paragon of the perfect fiasco. Another attempt was made in 1850, in Padua, but again unsuccessfully, until Ernesto Rossi performed Othello at Teatro Re in Milan, the same stage and the same play that had seen his master fail miserably about a decade before. This time the play was applauded and other productions followed that same year as well as in the next ones. Shakespeare was being widely accepted in the last decades of the century and his position in the Italian cultural system was only bound to grow. Another complete edition by Diego Angeli was published in 1911 and many other translations followed, including at least six more complete collections, with a significant increase from the 1960s. Only the sonnets had to wait until 1944 to be translated by Giuseppe Ungaretti, with very few other translations following, only one of which before the 1980s.

The relationship between Shakespearean drama and Italian melodrama, as well as ballet or other forms of adaptation, deserves a separate mention, as it followed a different course than that of translations and critical reception. Opera in nineteenth century Italy was as popular as drama in Elizabethan England and creativity in the area of melodrama was in constant ferment compared to the generally stale theatre production of those days. Up to about fifty compositions are directly or indirectly connected to Shakespeare's works. Even though this number is pretty high, the first that was directly derived from a Shakespeare's play, which is Verdi's Macbeth on Piave's libretto, is only dated 1847, about the same time when theatre performances were starting to be attempted. Ballet adaptations were somehow more precocious, the first being a Macbeth by dancer and choreographer Francesco Clerico, in 1802. There is also evidence of a Hamlet that was prohibited in Parma four years earlier, due to political concern of the authorities, who did not appreciate the number of assassinations in that story. There is also a quantity of theatre adaptation that often responded to the attempt of making Shakespeare's stories formally more acceptable to a public that was very hostile towards Shakespeare's chaotic and heterogeneous style and to the complete negligence for the Aristotelian units in the English drama. Even though they are mostly forgotten now, some of these adaptations were quite successful if Melchiorre Cesarotti judged Conti's Cesare superior to Shakespeare's (Collison-Morley 27).

Whatever their quality, however, they had some role in familiarizing the public with Shakespeare. It is necessary to point out that not all of these adaptations had Shakespeare as the main source, 
or even as a source at all, and derivations are not always so neat and easy to track. Shakespeare was himself a re-writer, so those stories that we now recognize as eminently Shakespearean, often had wider circulation in other versions rather than in Shakespeare's plays, especially up to the eighteenth century. The case of Zeno's Ambleto has already been mentioned and, yet, it is neither a surprising nor an uncommon one. Conti's Cesare was not a direct adaptation from Julius Caesar, but its writer had Shakespeare well present in mind. Bellini had probably never even read Shakespeare but derived his I Capuleti $e i$ Montecchi (1830) from Della Valle's Giulietta e Romeo, which bears resemblances with Shakespeare's play but could also have been inspired by any of the many re-writings of the story (Italian or French). Bandello's novella itself, the primary source of all these re-writings, ${ }^{2}$ had all but a marginal position in the Italian literary system of that time. These few examples should give a perspective on the high level of intertextuality Shakespeare's play were moving in.

\section{The problems of ethnocentrism and chronocentrism in textual exchange}

The difficulties of Shakespeare reception in Italy emerge clearly from this brief overview. Before trying to account for this fact, however, it will be necessary to address some problems on how questions related to canonization are approached in literary criticism. When trying to explain any criticism that is hostile to Shakespeare, a number of recurrent arguments appear frequently. These usually imply some form of blindness on the side of eighteenth and nineteenth century audiences and critics, some inability to recognize and understand a true genius that could not be reduced into the readymade categories of the time. Some of the most popular arguments are the attachment to the Aristotelian units or to other conventions of a stale dramatic tradition (Baretti; Graf 318; Collison-Morley 6-7, 23-25, 43, 91).

Even though many of these arguments are valid, they do not give a very satisfying idea of how Shakespeare might have been read in

\footnotetext{
${ }^{2}$ Bandello's version (dated 1554 ) is the one that popularized the story in Italy and abroad, but it was directly inspired by Luigi da Porto's Historia novellamente ritrovata di due nobili amanti (1530). This, in turn, was derived from the semi-comical Novella XXXIII (Mariotto e Ganozza) by Masuccio Salernitano (published posthumously in 1476 ), the very first source of the story that we know of. Masuccio's settings, names and tones are very different, but the plot is basically the same. Da Porto's version is similar in structure to Bandello's, but less famous.
} 
the eighteenth and nineteenth centuries. Assuming a privileged point of view over the past is a form of cultural centrism that too easily dismisses decades of critical debates that also involved some of the most brilliant minds in Europe. The implied logic behind this stance is a tautological one: those whose judgement was different from ours were wrong because their judgement was different from ours. If we are the true depositories of the Shakespearean truth, any different understanding is a misunderstanding, it is given no credit and needs to be explained as a paradox.

Irina Zvereva, in an article of 2013, tried to analyse some of the possible reasons for Shakespeare's scarce fortune in Italy, concluding that the most likely explanation was Italy's closure, even snobbery, to other cultures. She suggests the existence of an Italian myth of cultural superiority, a sort of conceited attitude that made it more difficult to introduce other cultural instances in a country that only accepted its own past as a model. A good part of her claim is based on some replies to an article of 1816 by Madame de Staël that invited the Italians to be more open to recent English and German poetry, as it could be a spring of new ideas to renovate a somewhat stale tradition. The replies were often harsh and pointlessly patriotic (all the translations, from this point on, are mine):

How can she expect that the Italians, whose ears are embalmed with the divine singing of a Tasso, a Petrarca, a Dante, a Metastasio and of a thousand other sublime swans, could find pleasure in those! (Zvereva 263)

Even if it is true that there was, in Italy, some resistance to Romantic ideas (or Madame de Staël would not have felt the need to write such an invitation), this kind of remarks does not even approach a description of the cultural situation in the country. The first problem with this theory is the significance of comments like this. Written by unidentified readers of a Milan paper, these statements are probably not much different in quality and tone from the comments that today flood social networks, news portals or YouTube pages with ethnocentrism, misquotations and hate-speech. Whether this comparison appears plausible or not, such comments are evidently But even if we gave any credit to them, there are countless instances of the opposite attitude. Already in the eighteenth century many Italian intellectuals were looking up to Britain as a model of civilization and prosperity. This remark by Alessandro Verri, one of the greatest enthusiasts for England and Shakespeare, speaks for itself: 
It is natural to our amour propre to regret our inferiority as a nation, but reason is on the side of the English. They are markedly superior to the rest of the Continent of Europe and are right to treat foreigners as slaves. (Collison-Morley 31)

This is probably one of the most extreme examples of a trend that was by no means uncommon. The admiration for England was not primarily of literary nature, but did not exclude literature in any way. Many British writers enjoyed very high status and had prompt reception in Italy. Milton was admired from the start, Swift was commonly read and Pope was probably one of the most appreciated British writer. Addison's Cato was held among the highest tragedies in the modern world, while there are several attempts to produce Italian equivalents of his Spectator. Gray and Young were translated and imitated frequently enough, while Macpherson's Ossian had countless admirers who classified it among the masterpieces of mankind, together with Dante, Homer and Milton's works. Translations were not uncommon either. In the eighteenth and nineteenth centuries there are at least fourteen complete Italian translations of Paradise Lost, whereas the failed or partial attempts amount to at least another six. Some of the translators are among the most eminent intellectuals of the time, like Ranieri de' Calzabigi or Ugo Foscolo. Lazzaro Papi's version is commonly read and studied even today, as it is Foscolo's translation of Sterne's A Sentimental Journey (Zvereva 259-60; Collison-Morley). If there was a prejudice in Italy, then, it was not generalized but specifically addressed to Shakespeare. Dismissing thorny criticism because it is in contrast with present day literary values through the assumption that an entire country's conviction of cultural superiority would prevent Shakespeare's acceptance, is probably an easy way to solve the question, but also a simplistic and widely incomplete one.

What has been said clearly should not imply that Shakespeare was not misunderstood in eighteenth century Italy. But if it is true that, to put it with Bloom, "every reading is a misreading," a better way to address the question would be to investigate what these misreadings consisted in. Shakespearevs works were very estranging for the Italian audience and they often made an extremely upsetting impression. The circumstances of the first performance of a Shakespeare play in Italy can illustrate this very effectively. Gustavo Modena was probably the most appreciated actor in Italy in the nineteenth century, with a steady 
international reputation (Collison-Morley 152). ${ }^{3}$ In the 1840s, he decided to perform Othello at Teatro Re in Milan and the outcome was disastrous. The audience was expecting to see a tragedy but, when they saw Roderigo and lago shouting in the street to warn Barbantio against the Moor, using sexual jokes and racist epithets, they started laughing and whispering, not knowing if they were watching a tragedy, a comedy or a farce. Soon it was impossible to continue the performance and curtains were drawn. Even though at least seven translations of Othello had been circulating in Italy for more than fifty years, the greater theatre public did not appreciate the abrupt changes in tone and register that is so common in Shakespeare. Ernesto Rossi, Modena's pupil, made a fresh attempt more than a decade after, with more careful preparations and a very different outcome. First of all, he opted for a different translation, as Leoni's, the one used by his master, was not to his taste, being "too much concerned with the times, the taste, habits and customs of the public" (Collison-Morley 155).

He liked Rusconi's enough but thought a stage performance should use a verse translation rather than a prose one, so he commissioned one from Giulio Carcano. The translation was ready in 1852 but Rossi felt he had to travel to Paris and London, where he saw some performances and met actor Charles Keanes. The production was only ready in 1856 but, this time, the Teatro Re responded positively. Shakespeare's plays thus moved from reading rooms to the stage for the first time.

The concerns of the wider theatre audience, on the other hand, had also been the concerns of the most cultivated reading public. The debate on Shakespeare had been animated by some judgements that frequently recurred. The readers of that time generally did not fail to notice what beauty was in Shakespeare's works, but they could not forgive his faults, which they perceived as much greater. The absence of the unities was seen as unbearably unrealistic, the mingling of comical and tragic elements, often in close contact, was inconceivable, the mix of poetry and prose was felt as clumsy. In the span of a few lines Shakespeare could go from very low, even trivial passages to the highest and most memorable ones, from banality to sublimity, a fundamental word in the aesthetic criticism of the time. Most readers simply could not bear it. The problem of Shakespeare's faults, however, was not absent from favourable criticism either. Even the enthusiasts felt they had to provide a

\footnotetext{
${ }^{3}$ Genevieve Ward considered him the best actor she had ever seen (Collison-Morley 152).
} 
justification for them, but they perceived that those were neatly surpassed by his merits (Collison-Morley 90). ${ }^{4}$ Many scholars tried to solve the problem by pointing out to the most troublesome sections as spurious additions. Some translators, as we will see, consequently felt entitled to obliterate entire passages from the texts.

The fact that Voltaire hugely influenced, or even prejudiced, Shakespeare criticism is very often, and quite correctly, observed. Voltaire was an opinion leader of tremendous authority and surely many judgements simply followed his own. This argument, though, is valid both ways and Shakespeare's works later enjoyed the support of equally influential intellectuals - such as, for instance, Goethe-who determined their success in the European canon. Such a thing as an unprejudiced opinion hardly exists at all and, yet, a judgement is not necessarily diminished by the fact that it is expressed within a given paradigm. On the other hand, it is equally iconoclastic to declare Shakespeare a genius when the few who know him consider him a barbarian without taste, as it is to judge him "a damn fool" (Webster 25-26) when the mainstream opinion has consecrated him to the highest place in modern literature.

The number of quotes that could exemplify the nature of the Shakespeare debate is virtually countless. The instance that is given here has particular significance. Ippolito Pindemonte remarked that

what is good in the tragedies of Shakespeare appears as very good because it is found among much bad. Some flowers are better liked in a wild field. True genius Shakespeare did not have, as genius does not split from taste. An ignorant he was not, but he had no faculty of invention. (Graf 325)

Pindemonte was a fine poet and translator, his version of the Odissey is commonly read in Italy even today and his opinion is interesting for at least two reasons. First of all, it summarizes the most common contemporary attitudes towards Shakespeare, without being

\footnotetext{
${ }^{4}$ "Who does not see the faults and extravagances of Dante and Shakespeare? Yet who does not feel his mind broadened and ennobled by reading these sublime authors." Ugo Foscolo, "Letter to Giambattista Giovio," 14 jan. 1809, (Collison-Morley 90). The parallel with Dante is very interesting. Even though the two have quite a different history in their appreciation in Italy and Europe, as well as different positions in those systems, both were undergoing a process of re-evaluation in literary criticism at the beginning of the century.

5 "Oh, what a damned fool Shakespeare was!," G.B. Shaw in a letter to Mrs Campbell (Webster 25-26).
} 
a lavish repetition of other ideas. Secondly, in spite of this remark, Pindemonte actually translated Shakespeare and the character of his translations is revelatory. He selected and translated only a few significant passages from several plays, as a sort of Shakespearean anthology. This choice is an emblematic statement: for Pindemonte, and for many of his contemporaries, the only way to make Shakespeare acceptable was to keep the "good" and discard the "bad," to select the "sublimity" and exclude the "triviality." ${ }^{16}$ This tendency to clean Shakespeare is very evident, as we will see, even in the extensive translations, especially the earliest ones.

The terms of the Shakespeare debate and his controversial canonization were approximately the same all around Europe and the Italian case, despite being particularly delayed, does not seem, in substance, so peculiar. As for the problem of translations, moreover, it has to be noted that they do not always find a direct place in a given culture, even when the text involved is extremely influential and unquestioningly accepted. The first complete English translation of Dante's Divine Comedy, for instance, was published in 1814, Petrarch's Canzoniere, arguably the most influential poetic text in Europe, only in 1854, while Bandello's Novelle, that inspired at least four plays of Shakespeare's, ${ }^{7}$ only appeared in English in 1890. Notwithstanding, all these texts kept on being influential in the British culture for centuries. Texts simply circulate in many rewritings of so many kinds that translations are often not even perceived as necessary. Texts' ways are infinite.

\section{Two translations of The Tempest: a case study}

The Tempest is a particularly interesting text in our study, because it is loaded with elements that might have been problematic to readers and challenging to translators. It is an unusual Shakespearean play, where magical elements are abundant, Christianity and paganism are mixed together, and the comical sections are considerable. It is also very visionary, almost of Romantic conception.

Here we will have a brief look at two translations: the one by Michele Leoni (1815) and the one by Giulio Carcano (published 1857-

\footnotetext{
${ }^{6}$ These terms are used, among others, by Calzabigi: "He mixed prose with verse and the trivial with the sublime, but with this peculiarity, that his trivial is that of the common herd, his sublime that of Longinus." (Collison-Morley 44-45).

${ }^{7}$ Romeo and Juliet, Cymbeline, Twelfth Night and part of Much Ado about Nothing. Also Webster, Fletcher, Massinger and Marston were influenced by Bandello's stories.
} 
59, here in the 1860 edition). Leoni's version is not particularly qualitative, but it is extremely interesting because it is the very first translation of this play and it will illustrate some peculiarities of the earlier approaches to Shakespeare. Carcano's is a later and more mature version that will show how those tendencies evolved through the years. Both translators had a very significant role in Shakespeare's reception, being the first and the last to translate a conspicuous corpus in the nineteenth century. The over forty years that separate them weigh as centuries in critical attitudes towards the author. Leoni's versions are those of the harshly debated and controversial Shakespeare, Carcano's are those of the canonized Shakespeare. Leoni's are the translations of Modena's fiasco, Carcano's are those of Rossi's success.

\section{Humour, puns, wordplay}

The comical scenes are probably among the most challenging to translators for several reasons. Humour is often culture-specific and difficult to be transferred across cultures or even across time within the same culture. The significant usage of puns in The Tempest makes this scenario obviously more difficult. To this, another contingent reason should be added. Puns and other such comical devices were pretty unpopular in nineteenth century Italy, not because they were alien to its tradition, but because they were too much in it. Italian Commedia dell'Arte used such repertoires abundantly and, while this genre had its time of acclaim and international prestige, it finally wore out and became quite repetitive. The fact that The Tempest bears similarities with a Commedia dell'Arte play ${ }^{8}$ (Vaughan) makes the scenario more interesting, as it might have made the play more familiar for the Italian audience, but also potentially less interesting.

It is not surprising, therefore, that Carcano feels the need to justify the presence of puns in a footnote at their first occurrence, in the opening part of the second act:

Some critics believed such puns to be interpolated by the actors themselves. In fact, it should be observed that Mr. Shakespeare, perhaps in no play more than in this one, proved himself sober in the use of such puns and wordplay. (Carcano 394)

\footnotetext{
${ }^{8}$ Vaughan and others identified striking resemblances between Prospero and Pantalone, Pulcinella and Caliban, while Stephano and Trinculo have their equivalents in Arlecchino and Brighella (Vaughan).
} 
$\mathrm{He}$, nonetheless, tries to render them as closely as possible. "He receives comfort like cold porridge," (The Tempest 2.1.10) based on the peace/peas pun of the preceding line, becomes "Il conforto gli sa buono / Come zuppa stantia" ("comfort tastes good to him, like stale soup," Carcano 216), where the pun is actually lost but the joke remains, with the addition of a sarcastic remark and an attempt to consolidate the effect of "cold porridge" with an even stronger "stantìa" (stale). A few lines below we find the exchange:

\section{Gonzalo}

When every grief is entertained that's offered, Comes to the entertainer--

\section{Sebastian}

A dollar.

\section{Gonzalo}

Dolour comes to him, indeed: you

have spoken truer than you purposed (Tmp. 2.2.16-20).

The pun dollar/dolour ${ }^{9}$ is made possible by the double meaning of "entertainer" as the one who suffers (entertains) grief or an innkeeper. The dialogue is translated:

\section{Gonzalo}

Se al dolor che su noi viene

Diam esca, allor s'addoppia, e ci rapporta...

\section{Sebastiano}

Una doppia

\section{Gonzalo}

È, di ver, doppio dolor

E diceste più ver che non pensate.

(-Gon. If we feed the grief that come to us, then it doubles, and it gives back -Seb. A coin/A double -Gon. It is, in truth, double grief, and you spoke more truly than you think. Carcano 394)

The pun is somehow maintained through the word "doppia," a coin used in several Italian states from the sixteenth to the nineteenth century, but otherwise simply meaning "double" in its feminine form. The translator still felt that further clarification was needed and added another footnote explaining the original wordplay. The first part of that

\footnotetext{
${ }^{9} \mathrm{Cf}$. King Lear 2.4.47: "But for all this thou shalt have as many dolors for thy daughters as thou canst tell in a year."
} 
scene keeps, in Carcano's version, a high rhythm and a playful tone, not distant from the English text. In Leoni, we observe a completely different approach.

\section{Insults, profanities and lower register}

Even though both translators use unrhymed hendecasyllables the standard choice to render English iambic pentameters and viceversa-Leoni's verse is a lot more regular and shows from the very beginning a clear effort to ennoble the unpredictable Shakespearean matter. The result, usually quite longer than the English text, is excessively mellifluous and pompous. The first line of the scene we just looked at, from

Beseech you, sir, be merry (Tmp. 2.1.1)

becomes

Datti pace, signor; e su tua fronte

Si distenda il seren del tempo antico.

(Be at rest, sir, and on thy brow / let the clear sky of old stretch out. Leoni 48)

where "seren" both means a clear sky and peace of mind. Similarly, a very simple

Prithee, peace (Tmp. 2.1.9)

can expand into

Deh, cessa omai! Fa ch'io rimanga in pace.

(Prithee, cease now! Let me stay at peace. Leoni 48)

Leoni is obviously trying to adjust the text to a different poetic standard, using the rhetoric of his time to produce a more harmonious and regular work. Some parts of the play simply could not adjust to that standard, so they were completely obliterated. From this line, the conversation with the puns and jokes is simply omitted and the play resumes when Gonzalo and Alonzo talk more seriously about their present situation. An omission is also a precise translation choice, and a very significant one, as it can reveal the translator's ideology more evidently than other choices.

The handling of low-tone passages, especially where insults and profanities are present, is, therefore, especially interesting. In the agitated opening scene of the play, the tension of the shipwreck is conveyed through an excited and violent dialogue. Leoni's rendering 
has melodramatic tones and loses the fragmentary character of the English. In Shakespeare's text, Antonio spits out a:

Hang, cur! Hang, you whoreson, insolent noisemaker! We are less afraid to be drowned than thou art (Tmp. 1.1.4344).

This is considerably smoothed down in Leoni's:

Un vincolo di fune

Ti soffochi la strozza, ente malnato, Senza pudor, senza pietà! Men duole

Per certo a noi che a te lo andar sommersi.

(May a rope's tie / Choke thy throat, uncouth being, / Shameless and pityless! Being sunken / is surely a lesser pain to us than is to you. Leoni 5)

Carcano makes harder efforts to strengthen the curses, that are profusely dispensed in the scene, but within certain limits. His version of the same lines is:

Va, t'appicca, o tristo

Schiamazzator ribaldo! D'annegarci

Temiam manco di te!

(Go hang yourself, wretched / rogue noismaker! The drowning / we fear less than you. Carcano 386)

"Va, t'appicca" is definitely more colloquial, immediate and less affected than "un vincolo di fune ti soffochi la strozza," but "tristo" (wretched) is quite a bland rendering of "whoreson." Despite the effort, profanities were inadmissible for nineteenth century prudish publishing conventions, so the translator opted for a blander alternative.

Most lexical choices in both translations conform to the language of contemporary drama and poetry (Abbatelli), but this tendency is much stronger in Leoni, who leans a lot more towards melodramatic and lofty solutions. This attitude often translates into a tendency to delete semantic areas that are not fully admitted in the artistic standard of the time, including those words that refer too precisely to concrete objects of our world. More vague or general terms are usually preferred to those. The first scene obviously abounds with nautical references that neither translator refuses to render 
concretely enough, but only to some extent. The word "cabins," for instance, has a close equivalent in Carcano's "caselli," but is systematically bypassed in Leoni, either through omission or circumlocution. "Any emperor that ever trod on neat's leather" in 2.2.70, becomes, in Carcano, "qual sia sovrano / Che i più morbidi cuoi s'adatti al piede" (any monarch / who fits the softest leather on his foot. Carcano 400). The reference to the animal is lost in favour of "morbidi" (soft), which conveys more meaning in this context, hinting at the economic value of the shoe. Still, the translator wants to recuperate what is lost, again through an explanatory footnote. Leoni, on the other hand, rejects all treading and shoes, cows and feet, and gives us: "che il più possente / Re della terra irne potria superbo" (that the most powerful / King on earth could be proud of him). Proud kings are obviously a more acceptable subject to Leoni's poetics than shoes made of cow's skin.

Some of the most visually strong metaphors produce very different approaches in the two translations.

A solemn air and the best comforter

To an unsettled fancy cure thy brains,

Now useless, boil'd within thy skull (Tmp. 5.1.58-60).

Leoni opts again for a decided attenuation, so the "useless brains" and the "skull" they boil inside, become a more abstract and cleaner "intelletto in disordine" (Leoni 138). Carcano, on the other hand, chooses to remain as literal as possible and tries to preserve the disturbing image.

Un'armonia solenne

E quanto può di turbato cerébro

Esser conforto, il tuo risani, or fatto

Inane e tal che dentro il cranio bolle.

(A solemn harmony / As much as it can be a comfort to an unsettled brain / May yours heal, that now is made / useless and such that it boils within thy skull. Carcano 413).

Even if the syntax is a bit clumsy and not immediately suggestive as in the English, the lexical choices show an effort to reproduce the same images without trying to tone them down. 


\section{Lyricism}

Finally, it is worth to look at some of the most lyrical and intense passages, to observe how the two translators handle the highest points of Shakespearean writing. Prospero's lines on the dissolution of the theatre of dreams and illusions as a metaphor of this life, are among the most famous and memorable in the play. Even here, Leoni shows the same tendency to sublimate the text into something more ethereal and eloquent. "And, like the baseless fabric of this vision, / The cloud-capp'd towers" (Tmp. 4.1.151-52) turns into "Fragili al par di queste aeree larve, / Le torri, che le nubi han per confine" (Frail like these aerial semblances / The towers, that have the clouds as boundaries. Leoni 123) where "larve" (semblances) is decidedly a Latinism and an archaism, while the towers have a more mellifluous "confine" (boundary), rather than a "cap". All the lexical choices tend to a lofty style, like "delubri" (temples), another Latinism, while "shall dissolve / And, like this insubstantial pageant faded, / Leave not a rack behind" (Tmp. 4.1.154-56) becomes, with a quasibaroque circumlocution, "Senza lasciar dietro alla sua rovina / Un segno pur, che l'universo attesti / All'infinito, andrà disciolto al nulla." (Without leaving behind its ruin / Even a sign, that vouches for the universe / To the infinity, will be dissolved into nothingness. Leoni 123). The famous lines

We are such stuff

As dreams are made on, and our little life

Is rounded with a sleep (Tmp. 4.1.156-58).

becomes

De' sogni al par, nostra sustanza è vana;

E sovra il breve cerchio della vita

Con perpetua vicenda il sonno posa.

(Just like dreams, our substance is empty; / And upon the brief circle of life / with perpetual succession sleep rests. Leoni 123)

The delicate and simple beauty of these verses is here transformed into a kind of philosophical gloss, with additions like "nostra sustanza" (our substance) and "perpetua vicenda" (perpetual succession), that seems to respond to some explanatory urge.

Carcano is committed to a closer rendering of the text 
E noi compon la stessa,

Sostanza inane, onde son fatti i sogni;

$E$ dal sonno cerchiata è questa nostra

Picciola vita.

(And we are made of the same / inane substance, whence dreams are made; / And circled by sleep is this our / little life.

Carcano 410)

The inclination to specify or expand the sense, through words like "compon" or "inane," is not completely absent, but it is considerably attenuated, and this version retains a lot of the sublunar beauty of Shakespeare's verses.

\section{Conclusion}

To conclude, Leoni's and Carcano's translations are very distant in terms of approach to the source text and translation choices. They belong to different aesthetic worlds but they effectively represent some specific attitudes of their own ages. Leoni seems too intent on purifying and assimilating Shakespeare to the poetic standards of his time. This kind of manipulation is not necessarily objectionable per se, but Leoni's attempt generally leads to clumsy results which failed to create a significant Shakespearean text in Italian. Trying to produce a more acceptable Shakespeare at the cost of sacrificing much of his nature, Leoni ultimately failed to achieve either acceptance in the target culture or authenticity. Still, his translation has the great merit to be the first in Italy and for years it was the only Tempest that many Italian readers could access to. The idea of Shakespeare that they might have derived from it perhaps did not help Shakespeare's fame in Italy, but it nonetheless introduced him in the Italian literary system. Carcano proved to be a more skilled mediator. His translation proceeds from a completely different attitude and, though his verse is a lot more regular than Shakespeare's and it partially preserves some of the previous tendencies, it testifies a different approach and a new understanding, which results into a more authentic rendering. What emerges from this analysis, therefore, is not only the fact that different approaches from different paradigms produce different translations, but also that the translations themselves are the engines that promote new attitudes and, in part, bring about paradigm shifts. It seems evident that literary works do not possess a universal value but that the latter is assigned within a specific system and is subject to change 
in time. Literary fame is not a destiny, but a destination. It is not the necessary unveiling of an absolute truth, the absence of which can only be treated as a paradox, but rather a construction which may or may not take place and that can assume many forms. The main focus about Shakespeare's canonization in Italy, therefore, should not be "why did it not happen?" but rather "how did it happen?" This second question, which is what this work has tried to address, proves to be more useful as it eliminates chrono-centric attitudes, is based on actual textual analysis rather than conjecture and, ironically, also provides interesting insight to the first one. The fact that Leoni's translation of Othello was used by Gustavo Modena in his ruinous production, while Carcano's marked the first success of a Shakespeare play, indicates-at least in part, since the all-important aspects of performance, production etc. are not analysed here-how important the translations were in mediating Shakespeare to the Italian audience and literary system.

\section{References:}

Abbatelli, Valentina. "L'italiano delle traduzioni di Shakespeare e Defoe tra Otto e Novecento." Diss. Università degli Studi di Roma La Sapienza. E-book.

Baretti, Giuseppe. Discours sur Shakespeare et sur Monsieur de Voltaire. London: Nourse, 1777.

Bloom, Harold. The Anxiety of Influence. A Theory of Poetry. New York: Oxford University Press, 1997. Print.

Carcano, Giulio, translator. Shakespeare, William. Teatro di Shakspeare, scelto e tradotto in versi da Giulio Carcano. Naples: Pasquale Sarpa, 1860. E-book.

Collison-Morley, Lacey. Shakespeare in Italy. Stratford-upon-Avon: Shakespeare Head Press, 1916. E-book.

Graf, Arturo. L'anglomania e l'influsso inglese in Italia nel secolo XVII. Torino: Loescher, 1911. E-book.

Leoni, Michele, translator. Shakespeare, William. La tempesta. Dramma di G. Shakspeare recato in versi italiani da Michele Leoni di Parma. Pisa: Niccolò Capurro, 1815. E-book.

Morandi, Luigi. Voltaire contro Shakespeare. Baretti contro Voltaire. Città di Castello: Lapi, 1884. E-book.

Shakespeare, William. The Annotated Shakespeare. New York: Greenwich House, 1988. E-book.

Shakespeare, William. The Tempest. Ed. Virginia Mason and Alden T. Vaughan. London: Arden Shakespeare, 2000. Print. 
Vaughan, Alden and Virginia Mason Vaughan, editors. The Tempest. A Critical Reader. London: Bloomsbury, 2014. E-book.

Webster, Margaret. Shakespeare Without Tears. New York and London: McGraw-Hill Book, 1942. Print.

Zvereva, Irina. "Per una storia della riflessione teorica sulla traduzione in Italia. La sfortuna di Shakespeare." Enthymema Nov. 2013: 257-68. E-book.

\section{LA RICEZIONE DI SHAKESPEARE IN ITALIA: DUE TRADUZIONI DE LA TEMPESTA COME CASO DI STUDIO}

La fortuna letteraria, per quanto possa talvolta parere immutabile, è sempre il frutto di un complesso processo di mediazione, fatto di rifiuti, negoziazioni, fraintendimenti, e persino sentimenti quali repulsione o devozione. In altre parole, la fama letteraria è una destinazione piuttosto che un destino. Se la fortuna di Shakespeare in Europa seguì un percorso decisamente tortuoso, la sua accettazione in Italia risulta ancor più problematica. Per tutto il Settecento, non vi è praticamente traccia di Shakespeare nella penisola, e la sua prima traduzione appare solo nel 1831. La prima messa in scena risale al 1843 circa, rivelandosi un completo fiasco. Solo dopo un ventennio, con la rappresentazione di Othello da parte di Ernesto Rossi nel 1856, Shakespeare incontra il plauso del pubblico. Da qui in poi, anche grazie all'influsso del melodramma, il lento processo di canonizzazione si avvia a compimento.

II caso dell'Italia si rivela utile per comprendere il funzionamento dei processi di canonizzazione. Questo lavoro si propone di investigare le ragioni di una tale refrattarietà da parte del sistema letterario italiano, ed esplorare come meccanismi di etnocentrismo e cronocentrismo siano all'opera in tali processi.

Infine, un'analisi contrastiva di due traduzioni de La tempesta (quella di Leoni del 1815 e quella di Carcano del 1860) mostrerà quanto le scelte di traduzione siano dettate dall'ideologia del traduttore e riflettano i paradigmi culturali delle epoche in cui sono prodotte, ma anche d'altra parte, quanto siano importanti nel dare forma a tali paradigmi e avviarne il cambiamento.

Parole chiave: Shakespeare, traduzione, manipolazione, Italia, canonizzazione, The Tempest, La tempesta, Leoni, Carcano, cronocentrismo. 


\section{Appendix}

\section{A chronology of Shakespeare's translations, performances and adaptations in Italy in the eighteenth and nineteenth centuries}

The following chronology covers the eighteenth and nineteenth centuries, and is divided into translations, adaptations of different kinds (ballet, opera or drama) and stage productions. The list of translations is, as far as my knowledge goes, exhaustive, while for the other categories only the first and the main events are registered.

\begin{tabular}{|c|c|}
\hline 1726 & $\begin{array}{l}\text { Antonio Conti, I/ Cesare. This was neither a translation nor a direct } \\
\text { adaptation, but Conti knew Shakespeare and his Julius Caesar. First } \\
\text { mention of Shakespeare in the eighteenth century. }\end{array}$ \\
\hline 1756 & $\begin{array}{l}\text { Domenico Valentini, II Giulio Cesare, Tragedia Istorica di Guglielmo } \\
\text { Shakespeare. The first Italian translation. }\end{array}$ \\
\hline 1768 & Alessandro Verri, Amleto. Unpublished. \\
\hline $1776-1783$ & $\begin{array}{l}\text { Pierre Letourneur (1737-1788), Théatre de Shakespeare, } 20 \text { vols. First } \\
\text { complete translation in French and the only source for many Italian } \\
\text { readers and even some translators. }\end{array}$ \\
\hline 1777 & Alessandro Verri, Otello. Unpblished. \\
\hline 1798 & A ballet on Hamlet is prohibited in Parma for political reasons. \\
\hline 1798 & $\begin{array}{l}\text { Giustina Renier Michiel, Opere drammatiche di Shakspeare (sic) } \\
\text { volgarizzate da una dama veneta: Ottello o sia il Moro di Venezia, } \\
\text { Coriolano, Macbeth. }\end{array}$ \\
\hline 1802 & $\begin{array}{l}\text { Francesco Clerico, Macbeth ossia I due spettri al convito, ballet } \\
\text { adaptation performed in Milan. }\end{array}$ \\
\hline 1804 & Salvatore Viganò, Coriolano, ballet adaptation. \\
\hline 1811 & $\begin{array}{l}\text { Ippolito Pindemonte, Saggi di Eloquenza Estratti dal Teatro di } \\
\text { Shakespeare (extracts) }\end{array}$ \\
\hline $1814-15$ & $\begin{array}{l}\text { Michele Leoni, tragedies (mostly in verse): Giulio Cesare (1811), } \\
\text { Amleto, Romeo e Giulietta, Cimbelino, Macbetto, Riccardo III, } \\
\text { Tempesta, Otello (1825). }\end{array}$ \\
\hline 1817 & Monti comments negatively on an adaptation of Hamlet \\
\hline 1818 & $\begin{array}{l}\text { Salvatore Viganò, Otello, ballet adaptation on music by Rossini and } \\
\text { others. }\end{array}$ \\
\hline 1826 & $\begin{array}{l}\text { Cesare della Valle, Giulietta e Romeo (adaptation, inspired Bellini's } \\
\text { opera). }\end{array}$ \\
\hline 1829-34 & Ignazio Valletta, Giulio Cesare (1829), Otello (1830), Coriolano (1834). \\
\hline 1830 & Giuseppe Nicolini, Macbet \\
\hline 1830 & Virginio Soncini, Otello and Macbeth \\
\hline 1830 & Antonio Cherubini, Le Tombe di Verona ossia Giulietta e Romeo, ballet. \\
\hline 1831 & Gaetano Barbieri, Romeo e Giulietta \\
\hline
\end{tabular}




\begin{tabular}{|c|c|}
\hline $1830-1$ & $\begin{array}{l}\text { Giunio Bazzoni and Giacomo Sornani, Otello, Macbeth, Re Lear, La } \\
\text { tempesta, Sogno di una notte di mezza estate, Romeo e Giulietta }\end{array}$ \\
\hline 1831 & Carlo Rusconi: complete works (in prose) \\
\hline 1843 & Giulio Carcano, Teatro scelto di Shakespeare \\
\hline ca. $1843-6$ & $\begin{array}{l}\text { Gustavo Modena interprets Othello in Milan. The production is a } \\
\text { complete fiasco. }\end{array}$ \\
\hline 1847 & $\begin{array}{l}\text { Francesco Maria Piave, Macbeth (for Verdi), first to attain to the } \\
\text { Shakespearean text rather than previous or successive sources. }\end{array}$ \\
\hline 1850 & Alemanno Morelli unsuccessfully plays Hamlet in Padua. \\
\hline 1856 & $\begin{array}{l}\text { Ernesto Rossi plays Othello and then Hamlet in Milan. First successful } \\
\text { representation of Shakespeare. He used Carcano's translations, } \\
\text { especially made for this production in } 1852 \text {. }\end{array}$ \\
\hline 1856 & Tommaso Salvini successfully plays Othello in Vicenza and Venice. \\
\hline 1858 & $\begin{array}{l}\text { Rossi plays Macbeth in Venice and King Lear in Turin, other productions } \\
\text { follow. }\end{array}$ \\
\hline 1858 & Luigi Gualtieri, Shakespeare, a biographical play on Shakespeare. \\
\hline 1857-59 & Giulio Carcano: selected plays (3 vols.) \\
\hline 1865 & Arrigo Boito: Amleto (libretto for Franco Faccio) \\
\hline 1869 & $\begin{array}{l}\text { Andrea Maffei, Otello and La tempesta. Perhaps translated from } \\
\text { Schiller. }\end{array}$ \\
\hline 1870 & $\begin{array}{l}\text { Cristoforo Pasqualigo, La tempesta, I due gentiluomini di Verona, Otello } \\
\text { (1887). }\end{array}$ \\
\hline $1875-82$ & Giulio Carcano: complete edition, 12 vols. \\
\hline 1887 & Arrigo Boito, Otello (libretto for Verdi) \\
\hline 1893 & Arrigo Boito, Falstaff (libretto for Verdi) \\
\hline
\end{tabular}

